\title{
A165 EFFECT OF THE PEG COMPONENT OF CERTOLIZUMAB PEGOL ON CALCIUM FLUX IN CELLULAR SYSTEMS
}

G Fossati, ${ }^{1}$ A Nesbitt' ${ }^{1}$ New Medicines, UCB, Slough, UK

\subsection{6/ard.2010.149013.8}

Background and objectives Certolizumab pegol (the only polyethylene glycolylated (PEG) Fab' anti-tumour necrosis factor (CZP)) has a very low incidence of injection site pain (ISP) in clinical studies. This could be due to inhibition of mast cell degranulation by the CZP PEG component. Mast cells could be involved in mediating ISP: they are present at high numbers in the skin and can rapidly secrete inflammatory mediators in preformed granules. Changes in $\mathrm{Ca}^{2+}$ flux are primary indicators of cell activation, and mast cell degranulation is preceded by $\mathrm{Ca}^{2+}$ flux into the cell. PEG binds to metal ions (in particular $\mathrm{Ca}^{2+}$ ). The aim of this study was therefore to determine if PEG could inhibit $\mathrm{Ca}^{2+}$ flux in a cellular system.

Materials and methods Peripheral blood monocytes, isolated using MACS beads, were incubated with the fluorophore Fluo-4. $\mathrm{Ca}^{2+}$ flux was measured using flow cytometry by detecting the Fluo-4 emission at $515-535 \mathrm{~m}$. Ionomycin was added at $2 \mu \mathrm{g} / \mathrm{ml}$ and the emission measured over a $4 \mathrm{~min}$ period relative to background (assessed prior to ionomycin addition). The effect of a range of concentrations of the $40 \mathrm{kDa}$ PEG component of CZP on $\mathrm{Ca}^{2+}$ flux induced by ionomycin was assessed. The effect of PEG on an ionomycin-induced $\mathrm{Ca}^{2+}$ flux in cultured mast cells was determined by a similar method but flux was measured using a fluorimeter.

Results Ionomycin caused a dramatic flux of $\mathrm{Ca}^{2+}$ in the monocytes. PEG caused a dose-dependent inhibition of $\mathrm{Ca}^{2+}$ flux over a range of concentrations from a minimum of $40 \mathrm{mg} /$ $\mathrm{ml}$. This is a physiological concentration of PEG as the equivalent local concentration of PEG which is injected into patients is $88.9 \mathrm{mg} / \mathrm{ml}$. The inhibitory concentration $\left(\mathrm{IC}_{50}\right)$ for inhibition of the $\mathrm{Ca}^{2+}$ flux caused by PEG was around $10 \mathrm{mg} / \mathrm{ml}$. The maximum inhibition observed was $84.2 \%$ obtained at $40 \mathrm{mg} /$ $\mathrm{ml}$, with the effect titrating out around $1 \mathrm{mg} / \mathrm{ml}$. In mast cells the $\mathrm{IC}_{50}$ was around $11 \mathrm{mg} / \mathrm{ml}$.

Conclusion The PEG component of CZP inhibits $\mathrm{Ca}^{2+}$ flux in monocytes and mast cells at a concentration relevant at the site of injection. This inhibition of $\mathrm{Ca}^{2+}$ flux could potentially explain the low levels of ISP observed with CZP in the clinic. This effect would only be observed at the site of injection as systemic concentrations of the drug are below the levels where an effect is seen. 